University of Nebraska - Lincoln

DigitalCommons@University of Nebraska - Lincoln

USDA National Wildlife Research Center - Staff Publications
U.S. Department of Agriculture: Animal and Plant Health Inspection Service

January 2007

\title{
Lagomorph and rodent responses to two protein hydrolysates
}

Julia A. Figueroa

Colorado State University, Fort Collins

Bruce A. Kimball

USDA-APHIS-WS, National Wildlife Research Center, bruce.kimball@ars.usda.gov

Kelly R. Perry

USDA-APHIS-WS, National Wildlife Research Center

Follow this and additional works at: https://digitalcommons.unl.edu/icwdm_usdanwrc

Part of the Environmental Sciences Commons

Figueroa, Julia A.; Kimball, Bruce A.; and Perry, Kelly R., "Lagomorph and rodent responses to two protein hydrolysates" (2007). USDA National Wildlife Research Center - Staff Publications. 783.

https://digitalcommons.unl.edu/icwdm_usdanwrc/783

This Article is brought to you for free and open access by the U.S. Department of Agriculture: Animal and Plant Health Inspection Service at DigitalCommons@University of Nebraska - Lincoln. It has been accepted for inclusion in USDA National Wildlife Research Center - Staff Publications by an authorized administrator of DigitalCommons@University of Nebraska - Lincoln. 


\title{
Lagomorph and rodent responses to two protein hydrolysates
}

\author{
Julia A. Figueroa ${ }^{\mathrm{a}, \mathrm{b}}$, Bruce A. Kimball ${ }^{\mathrm{b}, \mathrm{c}, *}$, Kelly R. Perry ${ }^{\mathrm{d}}$ \\ ${ }^{a}$ Department of Biology, Colorado State University, Fort Collins, CO 80523, USA \\ ${ }^{\mathrm{b}}$ USDA-APHIS-WS, National Wildlife Research Center, 4101 LaPorte Avenue, Fort Collins, CO 80521, USA \\ ${ }^{\mathrm{c}}$ Graduate Degree Program in Ecology, Colorado State University, Fort Collins, CO 80523, USA \\ ${ }^{\mathrm{d}}$ USDA-APHIS-WS, National Wildlife Research Center, 9730-B Lathrop Industrial Drive, Olympia, WA 98512, USA
}

Received 4 May 2007; received in revised form 10 July 2007; accepted 11 July 2007

\begin{abstract}
Various species of rodents and lagomorphs were used in bioassays to determine the effectiveness of protein hydrolysates (specifically hydrolyzed casein and gelatin) as herbivore repellents. Mixed sex groups of captive rabbits, pocket gophers, voles, and mountain beavers were offered hydrolyzed casein or gelatin test diets in single-choice tests following a training period with a hydrolysate-free diet. The effectiveness of either hydrolyzed casein or gelatin was dependent on the species. Hydrolyzed casein was identified as an effective repellent for mountain beavers and pocket gophers as these species showed a strong avoidance of hydrolyzed casein diets. Rabbits demonstrated slightly higher avoidance of the gelatin diets versus hydrolyzed casein. However, hydrolyzed casein and gelatin displayed little potential as repellents for voles as both products were readily consumed. Rather than universal application for all pest herbivores, test diet preferences suggest that repellent application depends on the pest species.
\end{abstract}

Published by Elsevier Ltd.

Keywords: Gelatin; Gopher; Herbivore; Hydrolyzed casein; Mountain beaver; Rabbit; Vole; Wildlife damage management

\section{Introduction}

Repellents deter herbivores by exploiting their fear of novel stimuli (shiny objects, odor sachets, predator odors, etc.; Sunnucks, 1998; Nolte and Wagner, 2000; Kimball and Nolte, 2006), altering the palatability of the food resource (Andelt et al., 1994; Lutz and Swanson, 1995; Mason et al., 1999; Nolte and Wagner, 2000; Kimball and Nolte, 2006), or producing a conditioned taste aversion (Nolte and Wagner, 2000; Baker et al., 2007). Each of these mechanisms may be effective, depending on the motivation of the individual herbivore. Habituation to novel stimuli may pose a problem when no negative consequences are experienced by the animal during the encounter with the novel stimuli (Nolte, 1999). Products that promote taste aversions offer the best efficacy even in highly motivated herbivores since their consumption may cause negative

\footnotetext{
*Corresponding author. USDA-APHIS-WS, National Wildlife Research Center, 4101 LaPorte Avenue, Fort Collins, CO 80521, USA. Tel.: + 19702666069 ; fax: + 19702666063 .

E-mail address: bruce.a.kimball@aphis.usda.gov (B.A. Kimball).
}

postingestive consequences (i.e. toxic malaise). However, these repellents may not be practical as toxic agents are unlikely to be approved for many commodities, particularly food products.

Hydrolyzed casein (HC) has recently been demonstrated to significantly reduce browsing by deer, even when alternative food choices are minimized (Kimball et al., 2005). Relative to commercial herbivore repellents, $\mathrm{HC}$ is inexpensive, readily available, and food safe. In addition, $\mathrm{HC}$ is exempt from US Environmental Protection Agency requirements for residue tolerance. Gelatin (GE) is another example of a protein hydrolysate (from the hydrolysis of collagen, the primary protein found in connective tissues of mammals). GE was also used in this study because of the observation that laboratory mice avoided GE to a greater extent than HC (K. Field, personal communication).

Preliminary two-choice tests suggested that rabbits and voles avoided GE versus control to a greater extent than $\mathrm{HC}$, while pocket gophers and mountain beavers avoided $\mathrm{HC}$ relative to the control more so than GE. However, two-choice tests are not sufficient for predicting repellency because the repellent must not only be avoided when 
alternative foods are available, but also reduce the intake of foods when no alternatives are present. Thus, we conducted a series of single-choice tests as a more appropriate test to evaluate the repellency of $\mathrm{HC}$ with pocket gophers and mountain beavers and the repellency of GE with rabbits and voles.

\section{Methods}

\subsection{Subjects}

Mixed-gender, captive subjects of each species were used in single-choice tests. The species tested were New Zealand white rabbit (Oryctolagus spp.), mountain beaver (Aplodontia rufa), Western pocket gopher (Thomomys mazama), and Townsend's vole (Microtus townsendii). Animal procedures were approved by the National Wildlife Research Center Institutional Animal Care and Use Committee. Single-choice tests were conducted during the period of July-September 2006.

Rabbits and mountain beavers were individually housed and tested in $8^{\prime} \times 8^{\prime} \times 10^{\prime}$ and $8^{\prime} \times 8^{\prime} \times 4^{\prime}$ outdoor pens, respectively. Test diets were offered to rabbits and mountain beavers in individual $8^{\prime \prime}$ plastic food bowls. Pocket gophers were individually housed and tested in $11^{\prime \prime} \times 14^{\prime \prime} \times 7^{\prime \prime}$ plastic rat cages equipped with wire bar lids. Voles were individually housed and tested in similar plastic mouse cages measuring $8^{\prime \prime} \times 12^{\prime \prime} \times 5^{\prime \prime}$ equipped with wire bar lids. Rodent cages were maintained in indoor environments kept at $68^{\circ} \mathrm{F}\left( \pm 2{ }^{\circ} \mathrm{F}\right)$ with a $9 \mathrm{~h}$ light cycle where the test diet could be accessed through the wire bar lids.

\subsection{Test diets}

Test diets were prepared with a kitchen-type bowl mixer. The appropriate ingredients were placed in the mixer and water was added to produce a dough consistency (Table 1). Each diet consisted of test protein (HC, GE, or cellulose) added to a foundation diet. The foundation ingredients

Table 1

Description of ingredients used in the preparation of various test diets

\begin{tabular}{ll}
\hline Diet & Ingredients \\
\hline Foundation & $250 \mathrm{~g}$ corn starch \\
& $150 \mathrm{~g}$ whole-wheat flour \\
& $300 \mathrm{~g}$ sucrose \\
& $61 \mathrm{~mL}$ corn oil \\
& $35 \mathrm{~g}$ salt mix \\
& $10 \mathrm{~g}$ vitamin mix \\
& $800 \mathrm{~g}$ foundation \\
Hydrolyzed casein & $200 \mathrm{~g}$ casein hydrolysate \\
& $800 \mathrm{~g}$ foundation \\
Gelatin & $200 \mathrm{~g}$ gelatin \\
Cellulose (control) & $800 \mathrm{~g}$ foundation \\
& $200 \mathrm{~g}$ cellulose \\
\hline
\end{tabular}

were corn starch (Dyets Inc., Bethlehem, PA), whole-wheat flour (King Arthur ${ }^{\circledR}$, Norwich, VT), sucrose $\left(\operatorname{Kroger}^{\circledR}\right.$, Cincinnati, OH), corn oil $\left(\mathrm{Crisco}^{\circledR}\right.$, J.M. Smucker Co., Orrville, OH), salt mix (AIN-76; Dyets Inc.), and vitamin mix (AIN-76A; Dyets Inc.). The volume of water required to prepare the dough was dependent on the test material added. The dough was spread with a rolling pin to produce a thickness of $2.0 \mathrm{~cm}$. Blocks measuring $8 \times 4 \times 2 \mathrm{~cm}$ were cut and then dried at $105^{\circ} \mathrm{C}$ in a food dehydrator (Sausage Maker Inc., Buffalo, NY) until a consistent mass was obtained. One batch tended to produce between 12 and 18 bars.

The training diet consisted of foundation and wholewheat flour. The control diet was prepared with foundation and cellulose (Dyets Inc.); the $\mathrm{HC}$ diet consisted of foundation and casein hydrolysate (HCA-411; American Casein Company, Burlington, NJ). GE diets were similarly prepared with foundation and GE (PolyPro 5000; PB Leiner Co., Jericho, NY).

\subsection{Training}

Subjects were adapted to the testing schedule with a 4-day training period. Subjects were food deprived overnight $(14 \mathrm{~h})$ after which they were offered the training diet for $4 \mathrm{~h}$. Intake of training diet (g) was determined by mass difference. Following the $4 \mathrm{~h}$ test period, the test diets were removed and the subjects were given access to their basal ration for $6 \mathrm{~h}$ - until the beginning of the next deprivation period. Subjects had ad libitum access to water throughout the experiment. The basal/maintenance diet for rabbits consisted of Purina ${ }^{\circledR}$ Rabbit Chow Complete Blend (PMI Nutrition International, Henderson, CO), supplemented with apple slices, until the study was completed. The three rodent species received Lab Diet \#5012 (PMI Nutrition, Inc.) supplemented with apple. Mountain beavers and pocket gophers were additionally provided alfalfa cubes in addition to rat diet and apple.

Following the training period, 16-18 subjects of each species were assigned to two treatment groups according to training diet intake (mass) such that mean intake and standard deviation were similar between treatments ( 8 or 9 subjects per treatment).

\subsection{Single-choice tests}

For all species, subjects in the protein treatment group were offered only the hydrolysate-containing diet and subjects in the control group were offered only the control diet for 4 consecutive days according to the schedule established in the training phase. Intake (mass) was recorded daily for each subject. Rabbits and voles assigned to the treatment group were offered GE diets, while mountain beavers and pocket gophers assigned to the treatment group were offered $\mathrm{HC}$ in the single-choice study. Control group subjects were offered the control diet, regardless of species. 


\subsection{Statistical analyses}

Intake data (grams) from single-choice tests were subjected to repeated-measures analyses of variance (ANOVA) using mixed procedure in SAS with the "repeated" statement in SAS (2002) with treatment (control, protein), gender, and treatment $\times$ gender interaction the betweensubjects effects, day and all possible interactions the within-subjects effects, and subject the random effect. Multiple comparisons of the least-square means were made with the "pdiff" option (SAS, 2002) in addition to the method of Benjamini and Hochberg (1995) to control false discovery rate. Separate models were constructed for each single-choice test. Residuals from all ANOVA models were inspected graphically for violations of ANOVA assumptions.

\section{Results}

\subsection{Hydrolyzed casein tests}

For mountain beavers, treatment $(p=0.0013)$ and treatment $\times$ gender $(p=0.03)$ were the only significant effects of the single-choice test (Fig. 1). Comparisons of means indicated that males offered the $\mathrm{HC}$ diet $(2.3 \mathrm{~g})$ consumed less than males offered control diet $(14.5 \mathrm{~g})$. Females did not differ between the two diet treatments $(p=0.35)$. The treatment $\times$ gender interaction was a likely result of low control diet intake of females $(8.4 \mathrm{~g})$. Intake of females offered the $\mathrm{HC}$ diet $(5.5 \mathrm{~g})$ was not significantly different from the male intake of $\mathrm{HC}$ diet $(p=0.27)$.

Among pocket gophers, treatment $(p=0.025)$ was the only significant effect for the single-choice test (Fig. 1). Gophers offered control diet $(3.7 \mathrm{~g})$ consumed twice as much as those offered $\mathrm{HC}$ diet $(1.8 \mathrm{~g})$ in single-choice tests.

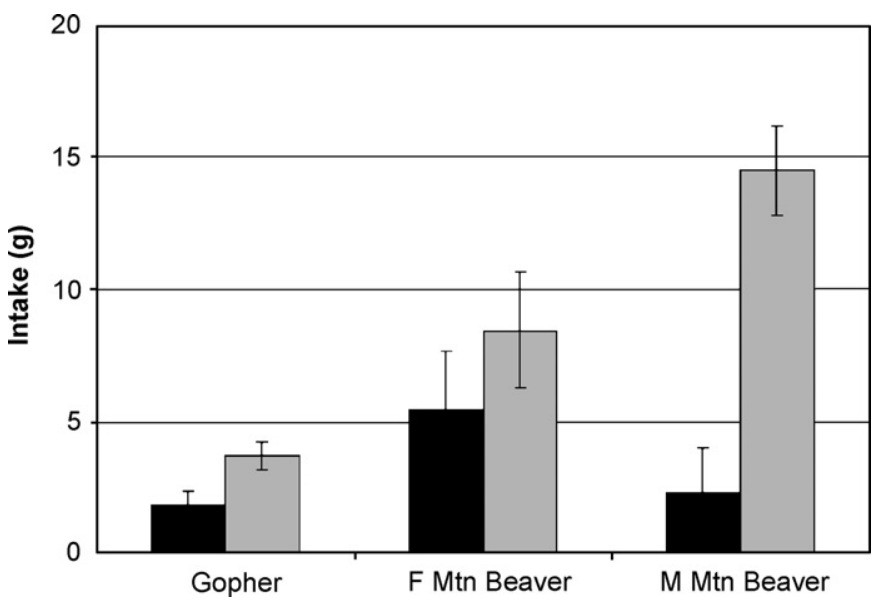

Fig. 1. Hydrolyzed casein intake during single-choice test for Western pocket gopher and mountain beaver: subjects were offered only hydrolyzed casein ( $\boldsymbol{\square})$ or control diet $(\square)$ according to treatment group in $4 \mathrm{~h}$ tests following food deprivation. Female (F) and male (M) mountain beavers responded differently to the hydrolyzed casein treatment.

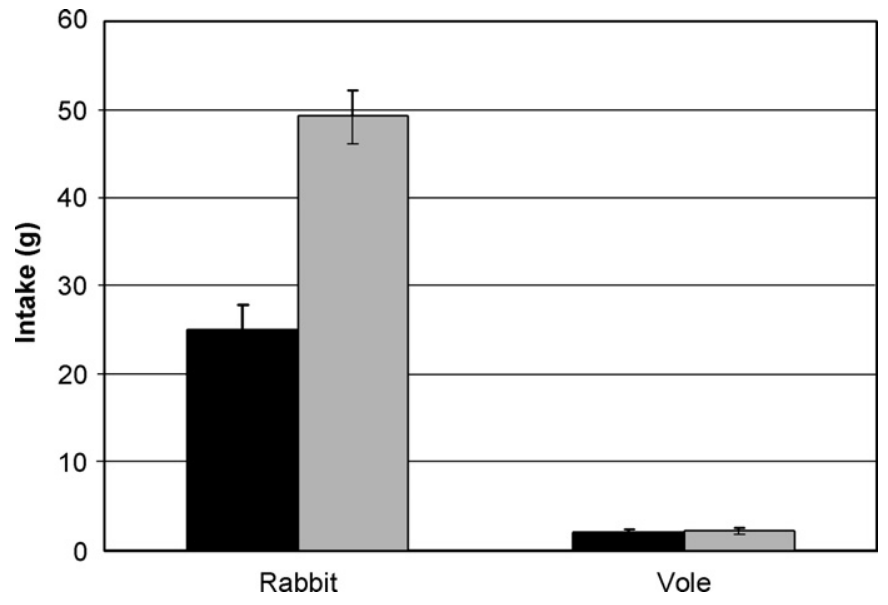

Fig. 2. Gelatin intake during single-choice test for New Zealand white rabbits and Townsend's voles: subjects were offered only gelatin $(\mathbf{\square})$ or control diet $(\square)$ according to treatment group in $4 \mathrm{~h}$ tests following food deprivation.

\subsection{Hydrolyzed collagen (gelatin) tests}

Analysis of intake data from single-choice tests with rabbits yielded significant day $(p=0.002)$, treatment $(p<0.0001)$, and gender $(p=0.036)$ effects. Rabbits offered control diet $(49.2 \mathrm{~g})$ consumed twice as much as rabbits offered the GE diet $(25.0 \mathrm{~g}$; Fig. 2). The intake of male rabbits $(42.0 \mathrm{~g})$ was greater than the females $(32.3 \mathrm{~g})$ and day 1 intake was lower than successive days (although there was no trend). There were no significant interactions.

Vole intake did not differ between treatments $(p=0.77)$ and day was the only significant effect $(p<0.0001)$ for the single-choice test (Fig. 2). Day 1 intake was lower than successive days and no trend was evident.

\section{Discussion}

Prior exposure to protein hydrolysates could potentially have influenced protein preferences in this study. For example, neonatal humans exposed to protein hydrolysate baby formulas demonstrate greater acceptance of these formulas later in life than those infants without the prior experience (Mennella et al., 2004). The basal diets offered to subjects in this study did not contain protein hydrolysates. Furthermore, mountain beaver, pocket gopher, and vole subjects were wild-caught, so previous contact with a protein hydrolysate was not a concern with these species. Inspection of the diet used in the rearing facility (Purina 5079, Agribrands Purina Canada, Woodstock, Ontario) of the laboratory rabbits indicated soybean as the major source of protein. Thus, test diet preferences observed in this study were probably not influenced by prior exposure to protein hydrolysates.

$\mathrm{HC}$ and GE diets themselves are not nutrient complete because they lack certain amino acids essential to the species' metabolism (Fisher, 1976; Friedman, 1996). 
It could be argued that reduced protein content (i.e. nutritional quality of the hydrolysates) may influence feeding preference. However, all species preferred the less nutritious control diet in this study. The cellulose diet contained less protein than either the GE or $\mathrm{HC}$ diets and therefore contributed even less to the overall nutrient intake of the animal. This suggests that the subjects' avoidance of the protein hydrolysates is not nutritionally driven, but affected by a factor within the protein that the subjects found unpalatable.

\subsection{Management implications}

Targeted application of the appropriate protein hydrolysate may prove efficacious for minimizing damagedepending on the pest species and its foraging behavior. Repellent effects of the two protein hydrolysates varied significantly among the four species tested. For example, protein hydrolysate avoidance by pocket gophers suggests that both GE and $\mathrm{HC}$ could be used as repellents. However, this species' fossorial behavior may make repellent delivery to affected plant parts impractical. $\mathrm{HC}$ appears to have great potential as a repellent for mountain beaver to reduce damage to conifer seedlings. This species' girdling and stem cutting behavior will require repellent application on the main stem of the plant near the base in addition to foliar application (Campbell, 1994).

Rabbits demonstrated strong avoidance of GE test diets. Application of a GE-containing repellent formulation offers great promise for minimizing rabbit damage to nursery and food crops. Both cottontail rabbits (genus Sylvilagus) and jackrabbits (genus Lepus) are specifically identified as problem vertebrate pests for various commodities such as orchards and ornamental plants (Craven, 1994; Knight, 1994). Cottontails have been identified as problem grazers to cereal crops (Bell et al., 1998; Fuchs and Neill, 1998) and forest trees (Whelan, 2000). Because GE is fit for human consumption (as is HC), registration for use as a tool to protect food products is likely. The results of this study strongly suggest that GE be investigated in field studies to determine its efficacy under natural conditions.

\section{Acknowledgments}

The authors are grateful to the Vertebrate Pest Control Research Advisory Committee (VPCRAC) of the California Department of Agriculture for research funding. Mention of specific products used in the tests does not constitute endorsement by the United States Department of Agriculture.

\section{References}

Andelt, W.F., Burnham, K.P., Baker, D.L., 1994. Effectiveness of Capsaicin and Bitrex repellents for deterring browsing by captive mule deer. J. Wildl. Manage. 58, 330-334.

Baker, S.E., Johnson, P.J., Slater, D., Watkins, R.W., Macdonald, D.W., 2007. Learned food aversion with and without an odour cue for protecting untreated baits from wild mammal foraging. Appl. Anim. Behav. Sci. 102, 410-428.

Bell, A.C., Byrne, P.M., Watson, S., 1998. The effect of rabbit (Oryctolagus cuniculus) grazing damage on the growth and yield of winter cereals. Ann. Appl. Biol. 133, 431-442.

Benjamini, Y., Hochberg, Y., 1995. Controlling the false discovery rate - a practical and powerful approach to multiple testing. J. R. Stat. Soc. Ser. B-Methodol. 57, 289-300.

Campbell, D.L., 1994. Mountain beavers. In: Hygnstrom, S.E., Timm, R.M., Larson, G.E. (Eds.), Prevention and Control of Wildlife Damage. University of Nebraska, Lincoln, NE, pp. D53-D60.

Craven, S.R., 1994. Cottontail rabbits. In: Hygnstrom, S.E., Timm, R.M., Larson, G.E. (Eds.), Prevention and Control of Wildlife Damage. University of Nebraska, Lincoln, NE, pp. D75-D80.

Fisher, H., 1976. Protein and amino acid requirements of the laboratory rabbit. Lab. Anim. Sci. 26, 659-663.

Friedman, M., 1996. Nutritional value of proteins from different food sources - a review. J. Agric. Food Chem. 44, 6-29.

Fuchs, R.M., Neill, G.J., 1998. A survey of rabbit damage and control measures used in the east and northeast of Scotland. In: Barker, R.O., Crabb, A.C. (Eds.), Proceedings of the 18th Vertebrate Pest Conference, 2-5 July 1998, Costa Mesa, CA.

Kimball, B.A., Nolte, D.L., 2006. Animal tissue-based herbivore repellents: scary odours or altered palatability? Adv. Vertebr. Pest Manage. 4, 59-72.

Kimball, B.A., Nolte, D.L., Perry, K.B., 2005. Hydrolyzed casein reduces browsing of trees and shrubs by white-tailed deer. HortScience 40, 1810-1814.

Knight, J.E., 1994. Jackrabbits and other hares. In: Hygnstrom, S.E., Timm, R.M., Larson, G.E. (Eds.), Prevention and Control of Wildlife Damage. University of Nebraska, Lincoln, NE, pp. D81-D85.

Lutz, J.A., Swanson, B.T., 1995. Reducing deer damage to woody and herbaceous plants. In: Mason, J.R., (Ed.), Proceedings of Repellents in Wildlife Management Symposium, 8-10 August 1995, Fort Collins, CO.

Mason, J.R., Hollick, J., Kimball, B.A., Johnston, J.J., 1999. Repellency of Deer Away Big Game Repellent ${ }^{\circledR}$ to eastern cottontail rabbits. J. Wildl. Manage. 63, 309-314.

Mennella, J.A., Griffin, C.E., Beauchamp, G.K., 2004. Flavor programming during infancy. Pediatrics $113,840-845$.

Nolte, D.L., 1999. Behavioral approaches for limiting depredation by wild ungulates. In: Launchbaugh, K.L., Sanders, D., Mosely, J.C. (Eds.), Grazing Behavior of Livestock and Wildlife. Idaho Forest, Wildlife \& Range Experiment Station Bulletin 70. University of Idaho, Moscow, ID, pp. 60-69.

Nolte, D.L., Wagner, K.K., 2000. Comparing the efficacy of delivery systems and active ingredients of deer repellents. In: Salmon, T.P., Crabb, A.C. (Eds.), Proceedings of the 19th Vertebrate Pest Conference, 6-9 March 2000, San Diego, CA.

SAS, 2002. SAS/STAT ver. 9.1. SAS Institute Inc., Cary, NC.

Sunnucks, P., 1998. Avoidance of novel objects by rabbits (Oryctolagus cuniculus L.). Wildl. Res. 25, 273-283.

Whelan, J., 2000. The impact of the European rabbit (Oryctolagus cunniculus) on forest trees. In: Salmon, T.P., Crabb, A.C. (Eds.), Proceedings of the 19th Vertebrate Pest Conference, 6-9 March 2000, San Diego, CA. 